\title{
Cowpea Yield Performance in an Alley Cropping Practice on an Acid Infertile Soil at Ebini, Guyana
}

\author{
Patrick E.K. Chesney*,1,3, Leslie A. Simpson ${ }^{2}$, R. Nigel Cumberbatch ${ }^{1}$, Oudho Homenauth ${ }^{1}$ and \\ Floyd Benjamin ${ }^{1}$
}

${ }^{I}$ National Agricultural Research Institute, Mon Repos East Coast Demerara, Guyana

${ }^{2}$ Caribbean Agricultural Research \& Development Institute, Kingston, Jamaica

${ }^{3}$ GSI Project, UNDP Guyana, 42 Brickdam and UN Place, Stabroek, Georgetown Guyana

\begin{abstract}
The yield performance of cowpea var. Minica \# 4 (Vigna unguiculata L.) on an Arenic Paleudult (Acrisol) was evaluated in an alley cropping experiment with Gliricidia sepium (Jacq.) Kunth ex Walp., Leucaena leucocephala (Lam.) de Wit and a treeless control during a short- (November-December 2004), and long-(May-June 2005) rainy season at Ebini, Guyana. The alley cropping treatments had no significant effect on cowpea plant height, pods per plant, pod weight per plant and grain weight. During the short-rainy season, values for cowpea plant height and number of pods per plant were higher compared to those for the long-rainy season, and number of pods per plant was positively correlated with pod weight. During the long-rainy season, pod weight and grain weight were correspondingly higher. Plant height vs. number of pods per plant; number of pods per plant vs. pod weight; and, number of pods per plant vs. grain weight, were all positively correlated. Cowpea could yield the same or more when associated with managed fast growing, nitrogen (N)-fixing trees or treeless plots. This alley cropping practice has the potential to reduce the use of fossil-fuel generated fertilizers and reduce the potential production of an important greenhouse gas (GHG).
\end{abstract}

Keywords: Humid tropics, sandy soils, agroforestry system, Gliricidia sepium, Leucaena leucocephala, Minica \#4, pruning.

\section{INTRODUCTION}

The Intermediate Savannas $\left(5^{0} 30^{\prime} \mathrm{N}, 58^{0} 00^{\prime} \mathrm{W}\right)$ of Guyana are located approximately $160 \mathrm{~km}$ south of the Atlantic Ocean behind the low-lying coastal plains. The climate is a transitional tropical wet and dry with mean annual rainfall of $2250 \mathrm{~mm}$, temperature of $26^{\circ} \mathrm{C}$, and relative humidity of $80 \%$ [1]. Dry evergreen forests dominated by wallaba (Eperua falcata Aubl.) and dakama (Dimorphandra conjugata (Splitg.) Sandwith), surround the native savanna vegetation consisting of grasses (Trachypogon plumosus (Humb. \& Bonpl. ex Willd.) Nees) and sand paper trees (Curatella americana L.). Soils of agricultural importance are loamy, siliceous, isohyperthermic, very acid, highly leached, and excessively permeable, of low natural fertility and exchange capacity [2].

Current efforts to develop the Intermediate Savannas for agricultural land-use are based on the perceived threat to the fertile, low-lying and populous coastal belt from sea level rise and increasing urbanization, and the need for alternative lands for commercial agriculture. Three decades of soil and crop research in the Intermediate Savannas have led to the development of cereal and grain legume crop rotation models. However, achieving economic crop yield on the soils of the Intermediate Savannas requires soil tillage, annual soil $\mathrm{pH}$ amelioration, fertilizers, and large scale cropping. For small farmers, the cost of these inputs is prohibitive.

*Address correspondence to this author at the GSI Project, UNDP Guyana, 42 Brickdam and UN Place, Stabroek, Georgetown Guyana;

Tel: (592) 223 6564; Fax: (592) 226 2942; E-mail: pekchesney@yahoo.com
Gliricidia sepium (Jacq.) Kunth ex Walp. and Leucaena leucocephala (Lam.) de Wit are fast growing, nitrogen $\left(\mathrm{N}_{2}\right)$ fixing trees for low-input tropical agroforestry systems with annual crops. The benefit of these tree species in agroforestry systems is increased when they are managed by pruning. Pruning management of the trees to reduce competition with companion crops for light and nutrients, to optimize supply of nutrients for crop growth, and to conserve the service attributes of trees which have developed under humid tropical conditions [3-7]. On an Arenic Paleudult soil in the Intermediate Savannas of Guyana, cowpea (Vigna unguiculata (L.) Walp.) and maize (Zea mays L.) had a greater yield in a three-year field trial when fertilized with leaf prunings of G. sepium and L. leucocephala compared to added chemical fertilizers [8].

The present study investigated the performance of cowpea in an alley cropping system with G. sepium, L. leucocephala and no-tree control on an acidic infertile Arenic Paleudult at Ebini, Guyana, to test the hypothesis that the introduction and management of fast growing, $\mathrm{N}_{2}$-fixing trees on smallholder farms provide an opportunity to reduce requirement for costly soil and crop inputs without concomitant loss in crop yield.

\section{MATERIALS AND METHODS}

\section{Study Site}

The study was carried out at the Intermediate Savannas Field Research Unit (ISFRU), of the National Agricultural Research Institute (NARI), Ebini, Guyana. The ecological 
zone is a transitional wet and dry savanna, approximately 28 $\mathrm{m}$ above sea level. The main soil type is an acid infertile Arenic Paleudult (Acrisol) soil [2]. Meteorological variables (average \pm SD) are monthly precipitation $178 \pm 76 \mathrm{~mm}$; rain days $15 \pm 4$ days; monthly mean temperature $26.7 \pm 0.74{ }^{0} \mathrm{C}$; and daily sunshine hours $5.5 \pm 1.0$ hours [1].

The experimental plots were established in March 1997 to evaluate the performance of cereal (Z. mays) and grain legume ( $V$. unguiculata) crops in alley cropping trials with $L$. leucocephala and $G$. sepium and treeless control treatments. $L$. leucopephala was established from seed and G. sepium from stem cuttings. Trees were planted at a row spacing of 6 $\mathrm{m}$ and an intra-row spacing of $1 \mathrm{~m}\left(1,666\right.$ trees $\left.^{-1} \mathrm{~h}^{-1}\right)$. Plot size was 15 × $6 \mathrm{~m}$.

Between 1998 and 1999, trees were managed by periodic aboveground leaf pruning carried out at the beginning and middle of the two cropping seasons per year (a total of four leaf prunings per year). Leaf prunings were added to the alleys formed by rows of trees, and cowpea, maize and sorghum (Sorghum bicolor L.) were planted in the alleys and treeless control plots [8].

\section{Experimental Design and Plot Management}

- The effect of trees and treeless control treatments on cowpea yield performance was studied in a randomized complete block design with six replications during the two cropping seasons. The treatments were L. leucocephala, G. sepium and treeless control. Cropping seasons were from November-December 2004 (short rainy season) and May-June 2005 (long rainy season). Plots were fallowed in the interval between crops and ploughed prior to sowing. Cowpea var. Minica \#4 was sown at a row spacing of $45 \mathrm{~cm}$ and an intra-row spacing of $4 \mathrm{~cm}$, in the alleys and in treeless plots. Plots were fertilized with compound fertilizer 12:12:17:2 at 12 days after sowing (DAS) and with tree leaf prunings at 35 DAS. During the short rainy season, $52 \mathrm{~kg}$ G. sepium and $13 \mathrm{~kg}$ L. Leucocephala leaf prunings were applied in-situ, and during the long rainy season, the respective amounts were, $57 \mathrm{~kg}$ and $14 \mathrm{~kg}$. Tree leaf prunings were not applied to treeless plots. On each pruning date, tree leaf fresh weight was measured before applying to plots. All plots were rain-fed irrigated and routine pest management practices were carried out. Cowpea was harvested at the grain stage.

\section{Statistical Analysis}

- Cowpea plant height, pods per plant, pod weight per plant and grain weight $(\sim 12 \%$ moisture content $)$ per plot data were examined for homogeneity of variances and normality. Harvest data from the two cropping seasons were combined. The effects of alley cropping treatments on these variables were analyzed using a SAS/GLM (SAS Institute, Cary, North Carolina) procedure for randomized complete block design with six replicates. Mean comparisons were by the Ryan-Elinot-Gabriel-Welsch (REGWQ) test $(P<0.05)$, which limits Type 1 experimental error. Pearson correlation procedures were applied to cowpea plant height and yield parameters. For all statistical analyses, the threshold probability level for determining significant differences was $\mathrm{P}>0.05$.

\section{RESULTS}

There were no significant differences among the alley crop treatments for any of the variables measured. Numerical values for the cowpea plant height and yield parameters were higher in tree plots when compared to the treeless control treatment (Table 1). When the cowpea data were analyzed by season, it was observed that plant height (Fig. 1), and pods per plant (Fig. 2) were higher during the short rainy season compared to the long rainy season. The reverse was true for pod weight (Fig. 3) and grain weight (Fig. 4).

Simple Pearson correlation procedures applied to the cowpea data revealed a positive correlation between number of pods per plant and pods weight per plant $(p=0.0900)$ during the short rainy season (Table 2). However, during the long rainy season, there were strong positive correlations between plant height and pod weight per plant $(p=0.0449)$, number of pods per plant and pod weight per plant $(p=0.0006)$, and number of pods per plant and grain weight per plot $(p=0.0017)$ (Table 3).

\section{DISCUSSION}

Results from this study confirm those of Simpson and Wickham [8] conducted under similar experimental conditions 4-5 years prior to this study. The inclusion of fast

Table 1. Effect of Alley Cropping Treatments with G. sepium and L. leucucephala and a Treeless Control on Cowpea Yield, Ebini During the 2004-2005 Cropping Season

\begin{tabular}{|c|c|c|c|c|}
\hline Treatment & $\begin{array}{c}\text { Plant Height } \\
\text { (cm) }\end{array}$ & Pods / Plant & $\begin{array}{c}\text { Pod wt. / Plant } \\
\text { (g) }\end{array}$ & $\begin{array}{c}\text { Grain wt. } \\
\text { (kg) }\end{array}$ \\
\hline G. sepium & $33.4 \mathrm{a}$ & $4.3 \mathrm{a}$ & $295.2 \mathrm{a}$ & $2.0 \mathrm{a}$ \\
\hline L. leucocephala & $32.1 \mathrm{a}$ & $4.1 \mathrm{a}$ & $289.9 \mathrm{a}$ & $1.8 \mathrm{a}$ \\
\hline Treeless control & $31.7 \mathrm{a}$ & $3.8 \mathrm{a}$ & $281.9 \mathrm{a}$ & $1.7 \mathrm{a}$ \\
\hline F-value & 0.21 & 0.16 & 0.06 & 0.81 \\
\hline $\operatorname{Pr}>\mathrm{F}$ & 0.9648 & 0.8562 & 0.9464 & 0.4552 \\
\hline C.V. (\%) & 20.58 & 58.41 & 34.05 & 33.37 \\
\hline
\end{tabular}




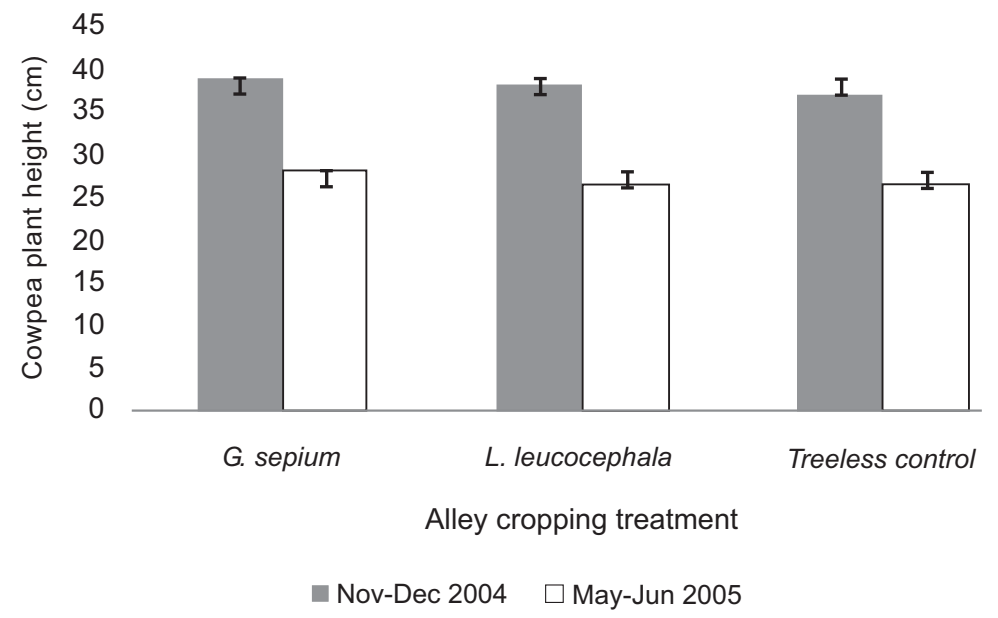

Fig. (1). The effect of G. sepium and L. leucocephala alley cropping and a treeless control on cowpea plant height in Ebini, Guyana.

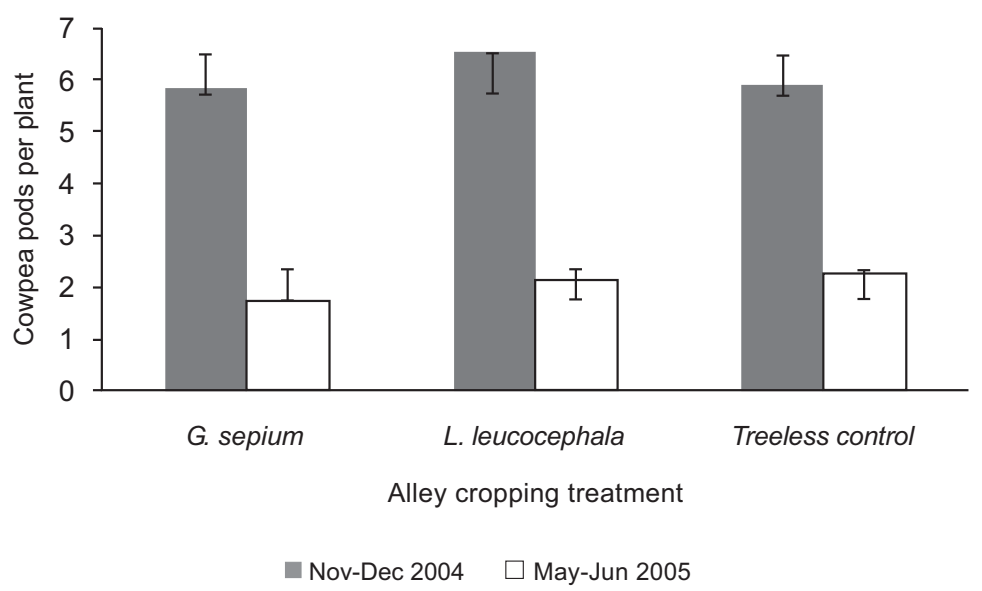

Fig. (2). The effect of G. sepium and L. leucocephala alley cropping and a treeless control on cowpea pods per plant in Ebini, Guyana.

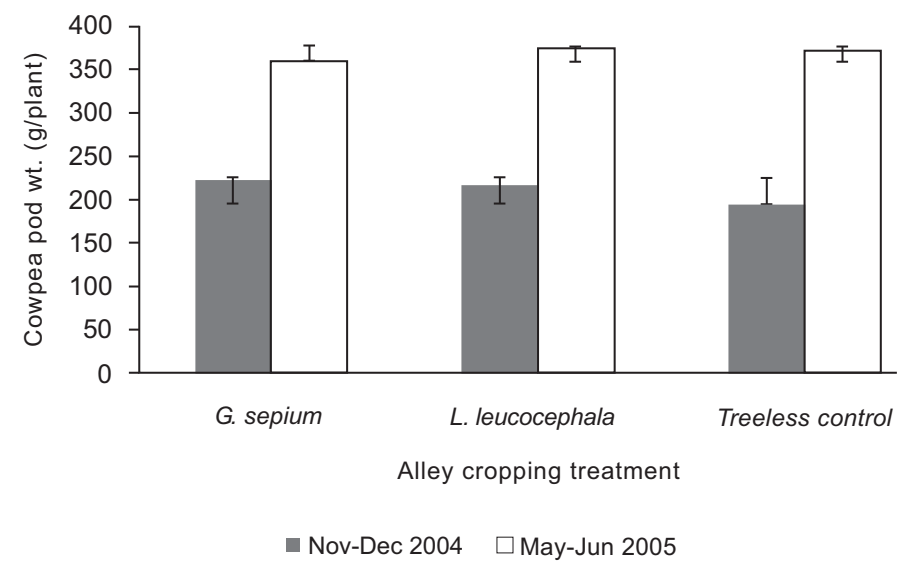

Fig. (3). The effect of G. sepium and L. leucocephala alley cropping and a treeless control on cowpea pod weight per plant in Ebini, Guyana.

growing, $\mathrm{N}_{2}$-fixing trees did not reduce yield of the companion cowpea crop over two cropping seasons. The reason may be attributed to the management of trees by periodic aboveground pruning and plowing before the cropping season. This suggests that aboveground pruning reduced the competition for light and nutrients, the latter owing to the deleterious effect of aboveground pruning of alley cropping trees on tree fine roots [3-4]. The contributory effect of plowing on avoidance of root competition, while not investigated in this study, is plausible [9]. In earlier agroforestry experiments when tree management by pruning was not practiced, agroforestry systems with Leucaena and Gliricidia drastically suppressed cowpea grain and yield, and average cowpea yield in agroforestry systems was $30-50 \%$ of the treeless control [10]. 


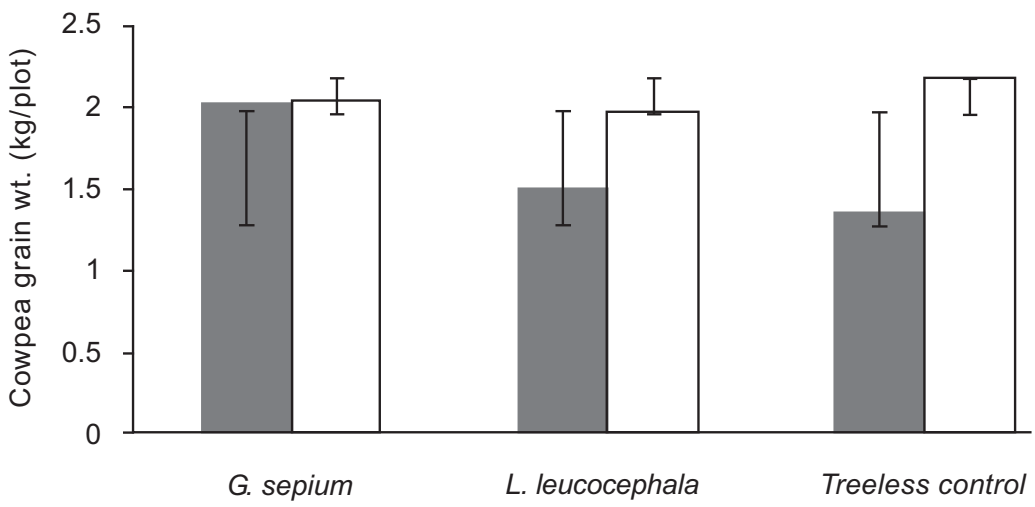

Alley cropping treatment

- Nov-Dec $2004 \quad \square$ May-Jun 2005

Fig. (4). The effect of G. sepium and L. leucocephala alley cropping and a treeless control on cowpea grain weight in Ebini, Guyana.

Table 2. Pearson Correlation Coefficients $(n=18)$ for Cowpea Variables During the Short Rainy Season (November-December 2004), Ebini, Guyana

\begin{tabular}{|c|c|c|c|c|}
\hline & Plant Height & Pods per Plant & Pod wt. / Plant & Grain Weight \\
\hline \hline Plant height & & -0.07243 & 0.35563 & 0.1475 \\
& & 0.7752 & 0.41120 & 0.23671 \\
\hline Pods per plant & -0.07243 & & $\mathbf{0 . 0 9 0 0}$ & 0.16368 \\
& 0.7752 & & & 0.5164 \\
\hline Pod wt. / plant & 0.35563 & 0.41120 & 0.30169 \\
& 0.1475 & $\mathbf{0 . 0 9 0 0}$ & 0.30169 & 0.2237 \\
\hline Grain weight & 0.23671 & -0.16368 & 0.2237 & \\
& 0.3443 & 0.5164 & & \\
\hline
\end{tabular}

Table 3. Pearson Correlation Coefficients $(n=18)$ for Cowpea Variables During the Long Rainy Season (May-June 2005), Ebini, Guyana

\begin{tabular}{|c|c|c|c|c|}
\hline & Plant Height & Pods Per Plant & Pod wt. / Plant & Grain Weight \\
\hline \hline Plant height & & 0.15161 & 0.47778 & 0.36539 \\
& & 0.5481 & $\mathbf{0 . 0 4 4 9}$ & 0.1359 \\
\hline Pods per plant & 0.15161 & & 0.72792 & 0.68432 \\
& 0.5481 & & $\mathbf{0 . 0 0 0 6}$ & 0.0017 \\
\hline Pod wt. / plant & 0.47778 & 0.72792 & & 0.1803 \\
& $\mathbf{0 . 0 4 4 9}$ & $\mathbf{0 . 0 0 0 6}$ & & \\
\hline Grain weight & 0.36539 & 0.68432 & 0.33057 & 0.1803 \\
\end{tabular}

Cowpea grain yield in this study was higher during the long rainy season compared to the short rainy season possibly because less photosynthates were allocated to vegetative growth (lower plant height) and comparatively more to grain production (higher pod and grain weights) [11]. Overall, cowpea grain yield ranging from $189-222 \mathrm{~kg} \mathrm{ha}^{-1}$ for all treatments was lower than that reported by Simpson and
Wickham [8], probably owing to better soil conditions for plant growth then, when plots were treated with diammonium phosphate at a rate of $100 \mathrm{~kg} \mathrm{ha}^{-1}$. This treatment was not repeated in 2004-05, when the present experiment was conducted.

When submitted to pruning schemes, fast growing $\mathrm{N}_{2}$ fixing tree species like G. sepium and L. leucocephala can be 
introduced on smallholder farms on acid infertile Arenic Paleudults (Acrisol) under variable rainfall conditions without the grain yield reducing effect on the cowpea companion crop. This practice is attractive for its potential cost savings in terms of the additional need of inorganic fertilizer additions; especially given the remoteness of the Intermediate Savannas from fertilizer supply companies. Soil amelioration with di-ammonium phosphate would be important as it may provide suitable growth conditions for the cowpea crop. While Gliricidia is tolerant to soil acidity, Leucaena is not [12].

The numerically higher cowpea yields obtained from Gliricidia-amended plots, its ease of establishment from cuttings and production of higher amounts of biomass, make Gliricidia a more attractive alley cropping species than Leucaena. As such, we recommend $G$. sepium with cowpea agroforestry practice in order to maximize crop yield and minimize the need for external nitrogen fertilizers. This will also reduce the potential production of $\mathrm{N}_{2} \mathrm{O}$, a GHG with a significantly higher global warming potential than $\mathrm{CO}_{2}$.

\section{ACKNOWLEDGEMENTS}

An International Foundation for Science grant (2957/2) to the first author supported this study. The authors thank the two anonymous reviewers for their useful comments.

\section{REFERENCES}

[1] Ministry of Agriculture. Average weather conditions in Guyana. Hydrometeorological Service, Ministry of Agriculture, Guyana. $1997 ;$ p. 8.
Simpson LA. Some aspects of soil physical characteristics and their management in the Intermediate Savannahs of Guyana. In: Walmsley D, Ed. Farming systems for low-fertility acid sandy soils, CTA Seminar Proceedings 1989; pp. 52-68

[3] Chesney P. Nitrogen and fine root length dynamics in a tropical agroforestry system with periodically pruned Erythrina poeppigiana. Agrofor Syst 2008; 72: 149-59.

[4] Chesney P, Nygren P. Fine root and nodule dynamics of Erythrina poeppigiana in an alley cropping system in Costa Rica. Agrofor Syst 2002; 56: 259-69.

[5] Haggar JP, Tanner E, Beer J, Kass D. Nitrogen dynamics of tropical agroforestry and annual cropping systems. Soil Biol Biochem 1993; 25(10): 1363-78.

[6] Kass DL, Araya J, Sanchez J, Soto L, Ferreira P. Ten years experience with alley farming in Central America. In: Kang BT, Osiname A, Larbi A, Eds. Alley Farming Research and Development Proceedings of the International Alley Farming Conference, Ibadan, Nigeria, 14-18 September 1992, IITA. 1995; pp. 393-402.

[7] Muschler RG, Nair PKR, Meléndez L. Crown development and biomass production of pollarded Erythrina berteroana, E. fusca and Gliricidia sepium in the humid tropical lowlands of Costa Rica. Agrofor Syst 1993; 24: 123-43

[8] Simpson LA, Wickham C. The performance of cowpea, maize and sorghum in alley cropping trial with Leucaena and Gliricidia in the Intermediate Savannahs of Guyana, CARDI, Guyana 2000; p. 12.

[9] Chesney P, Vasquez N. Dynamics of non-structural carbohydrate reserves in pruned Erythrina poeppigiana and Gliricidia sepium trees. Agrofor Syst 2007; 69: 89-105.

[10] Lal R. Agroforestry systems and soil surface management of a tropical alfisol: I: soil moisture and crop. Agrofor Syst 1989; 8(1): $7-29$

[11] Chesney PEK. Pruning effects on roots of nitrogen fixing trees in the humid tropics. Ph.D. Dissertation in Tropical Agoroforestry. CATIE, Turrialba, Costa Rica 2000; p. 167.

[12] Nair PKR. An Introduction to Agroforestry. Kluwer: Dordrecht, The Netherlands 1993; p. 499.

This is an open access article licensed under the terms of the Creative Commons Attribution Non-Commercial License (http://creativecommons.org/licenses/ by-nc/3.0/) which permits unrestricted, non-commercial use, distribution and reproduction in any medium, provided the work is properly cited. 